\title{
Atmospheric sulfuric acid leaching thermodynamics from metallurgical zinc-bearing dust sludge
}

\author{
Jinxia Zhang ${ }^{1,2}$, Weiguang Sun ${ }^{1}$, Fusheng $\mathrm{Niu}^{1,2^{*}}$, Long Wang ${ }^{1}$, Yawei Zhao ${ }^{1}$, Miaomiao Han ${ }^{1}$ \\ ${ }^{1}$ College of Mining Engineering, North China University of Science and Technology, Tangshan 063210, China \\ ${ }^{2}$ Hebei Province Mining Industry Develops with Safe Technology Priority Laboratory, Tangshan 063210, China
}

Corresponding Author Email: niufusheng@126.com

https://doi.org/10.18280/ijht.360131

Received: 3 August 2017

Accepted: 18 October 2017

\section{Keywords:}

zinc-bearing dust sludge, leaching, thermodynamics, potential $(\varphi)$ - $p H$ dominant area diagram

\begin{abstract}
In this paper, the influence of zinc and iron reaction in sulfuric acid leaching system, the influence of the parameters on the leaching of zinc sulfate and the reaction conditions for the subsequent leachate purification were systematically studied. It is suggested that the primary zinc and iron phases in metallurgical zinc-bearing dust sludge are $\mathrm{ZnO}, \mathrm{ZnS}, \mathrm{ZnFe}_{2} \mathrm{O}_{4}, \mathrm{Fe}_{\text {, }}$ $\mathrm{Fe}_{2} \mathrm{O}_{3}$ and $\mathrm{Fe}_{3} \mathrm{O}_{4}$. In $\mathrm{Zn}-\mathrm{Fe}-\mathrm{H}_{2} \mathrm{O}$ system, as the concentrations of zinc and iron ions in solution increase, each component therein remains unchanged. The dominant area is subjected to change with solution $\mathrm{pH}$. When the potential and $\mathrm{pH}$ are respectively controlled within a different scope, $\mathrm{Zn}$, Fe separation proceeds at the different levels. $\mathrm{Fe}_{2} \mathrm{O}_{3}$ is difficult to be leached when sulfuric acid is used as an agent. $\mathrm{ZnO}$ is leached while the iron ion is inhibited by $\mathrm{pH}$ control. It is found by comparison of $\lg [\mathrm{C}]-\mathrm{pH}$ maps of $\mathrm{Fe}_{2} \mathrm{O}_{3}$ and $\mathrm{Fe}(\mathrm{OH})_{2}, \mathrm{Fe}(\mathrm{OH})_{3}$ that in the treatment of subsequent leachate, $\mathrm{Fe}^{2+}$ can be oxidized into $\mathrm{Fe}^{3+}$ by adding an proper amount of the oxidant to solution, and $\mathrm{Fe}^{3+}$ forms $\mathrm{Fe}(\mathrm{OH})_{3}$ sediment by additive $\mathrm{NaOH}$ in solution. This hits the mark of iron removal. The research results have important theoretical significance for the leaching and purification process of alkali leaching-electrolysis process.
\end{abstract}

\section{INTRODUCTION}

China is the largest country of zinc production and consumption in the world. In 2015, China's zinc outputs reached 6.27 million tons, up 2.0\% YoY, more than one-third of the world's total zinc outputs. As a powerful support for the zinc smelting industry, the zinc output has fallen well short of what's needed in domestic market since a great deal of imports are yet still required in China [1-2]. As a result, zinc-bearing dust sludge has become an important source of regenerated zinc raw materials in our country. Based on China's crude steel output of 808 million tons in 2016, that is, only last year, the output of metallurgical dust sludge in China's iron and steel industry hit upon 80 million tons or so, containing $4 \sim 16$ million $t$ zinc, 24 million tons iron. If this part of zinc resources can be recovered, this has a great significance to promote the resource conservation and sustainable development, thus improving the economic efficiency and competitiveness of enterprises [3-4].

In recent years, quite a lot of studies at home and abroad have involved the zinc-bearing dust sludge, but most of them only focused on the zinc recovery process, mainly including hydrocyclone extraction of zinc [5], zinc extraction by hydrometallurgical leaching [6-7], zinc extraction by pyrogenic process and wet-fire joint process [8-9]. Zinc leaching thermodynamics from zinc-bearing dust sludge was seldom reported. In this regard, the reduction and zinc hydrometallurgy thermodynamics have increasingly won the favor of scholars [10]. Bai Shiping [11] turned out from the analysis of blast furnace gas slime reduction thermodynamics that the reduction of blast furnace gas slime was reached in a very short time $(20 \sim 40 \mathrm{~min})$ at a higher temperature. The reduction of each metallic oxide occurred at a relatively low start temperature: $\mathrm{ZnO}$ started to reduce at a temperature of $952^{\circ} \mathrm{C}$, the $\mathrm{PbO}$ at $281.9^{\circ} \mathrm{C}, \mathrm{Fe}_{2} \mathrm{O}_{3}$ at $324.5^{\circ} \mathrm{C}, \mathrm{Fe}_{3} \mathrm{O}_{4}$ at $664.2^{\circ} \mathrm{C}$, and $\mathrm{FeO}$ at $705.5^{\circ} \mathrm{C}$. Ding Zhiying et al. [12] expolored the thermodynamics of zinc hydrometallurgy process using the Chemical Equilibrium Modeling Code (CEMC). The results show that the zinc-containing species are mainly ammonia and hydroxylamine complex. $\mathrm{Zn}\left(\mathrm{NH}_{3}\right)_{2}{ }^{4+}$ in weak alkaline solution exists in the $\mathrm{Zn}(\mathrm{II})-\mathrm{NH}_{3}-\mathrm{H}_{2} \mathrm{O}$ and $\mathrm{Zn}(\mathrm{II})-\mathrm{NH}_{3}-\mathrm{Cl}-\mathrm{H}_{2} \mathrm{O}$ systems. In the $\mathrm{Zn}(\mathrm{II})-\mathrm{NH}_{3}-\mathrm{Cl}-\mathrm{H}_{2} \mathrm{O}$ system, ternary complex containing ammonia and chloride increases the solubility of zinc in the neutral solutions. There are three zinc compounds, i.e. $\mathrm{Zn}(\mathrm{OH})_{2}, \mathrm{Zn}(\mathrm{OH})_{1.6} \mathrm{Cl}_{0.4}$ and $\mathrm{Zn}\left(\mathrm{NH}_{3}\right)_{2} \mathrm{Cl}_{2}$, according to the total ammonia, chloride and zinc concentrations. The solubility of zinc depends on three compounds. These thermodynamic diagrams illustrate the impact of ammonia, chloride and zinc concentrations on zinc solubility and provide a thermodynamic reference for zinc hydrometallurgy.

In the first part of the article, the mineral composition, chemical composition and phase analysis of zinc-bearing steel dust were carried out. Then, the available data were used to calculate the standard Gibbs free energy for each leaching reaction. Under the given conditions, Booth free energy and reaction equilibrium constant $\mathrm{K}$, and finally using the thermodynamic principle and existing thermodynamic data to draw the corresponding system potential-pH diagram and $\lg [\mathrm{C}]-\mathrm{pH}$ map, through the thermodynamic equilibrium diagram can be quickly understood as the conditions required to extract a product or purify a solution. The research results can maximize the leaching rate of zinc and provide a reliable theoretical basis for secondary resource utilization of steel zinc dust. 


\section{MATERIALS AND METHODS}

\subsection{Nature of raw materials}

The Metallurgical Zinc-Bearing Dust Sludge used in the experiment is sourced from a steel mill in Hebei Province. The results from chemical multi-element analysis are shown in Table 1. The chemical composition analysis in Table 1 was provided by Northeastern University Testing Center. The Xray diffraction (XRD) and mineral phase analysis of zincbearing dust are shown in Fig. 1 and Table 2.

Table 1. Chemical composition analysis results of the zinc-bearing dust sludge $/ \%$

\begin{tabular}{ccccccccccc}
\hline Element & $\mathrm{TFe}$ & $\mathrm{Zn}$ & $\mathrm{MgO}$ & $\mathrm{SiO}_{2}$ & $\mathrm{CaO}$ & $\mathrm{Al}_{2} \mathrm{O}_{3}$ & $\mathrm{Cl}$ & $\mathrm{K}_{2} \mathrm{O}$ & $\mathrm{C}$ & other \\
\hline Content & 28.45 & 8.71 & 2.91 & 14.32 & 4.56 & 7.23 & 1.87 & 0.45 & 19.84 & 11.65 \\
\hline
\end{tabular}

It can be seen from Table 1 that iron, carbon and zinc are the primary valuable elements in Zinc-bearing dust sludge, followed by silicon, aluminum and calcium. The chlorine content is $1.87 \%$, as a catalyst which causes water corrosion, and can destroy the oxide film, soluble in water, speeding up the corrosion rate of the metal surface.

As shown in Fig. 1, the composition of the zinc-bearing dust sludge raw material is complex, contains some zinc-bearing minerals such as zinc oxide $(\mathrm{ZnO})$, zinc sphalerite $(\mathrm{ZnS})$, franklinite $\left(\mathrm{ZnFe}_{2} \mathrm{O}_{4}\right)$, aluminum zine sulfate $\left(\mathrm{ZnSO}_{4}\right)$, some iron mines such as hematite $\left(\mathrm{Fe}_{2} \mathrm{O}_{3}\right)$, magnetite $\left(\mathrm{Fe}_{3} \mathrm{O}_{4}\right)$, also some carbons and a small amount of meteorine, zeolite, calcite and other silicate minerals.

From the analysis of mineral phase in Table 2, it is known that the oxidation degree of the raw material is heavy. The main zinc minerals are $\mathrm{ZnO}$, followed by $\mathrm{ZnS}$ and $\mathrm{ZnFe}_{2} \mathrm{O}_{4}$, of which the content of $\mathrm{ZnS}$ accounts for $2.51 \%$. for this kind of minerals, a selective enrichment by mineral separation gets more difficult, and generally can be achieved by pressure or oxygen pressure acid leaching; zinc sulfate accounts for $0.45 \%$, relatively low as it is, in the subsequent leaching process $\mathrm{ZnO}$ is aimed for leaching.

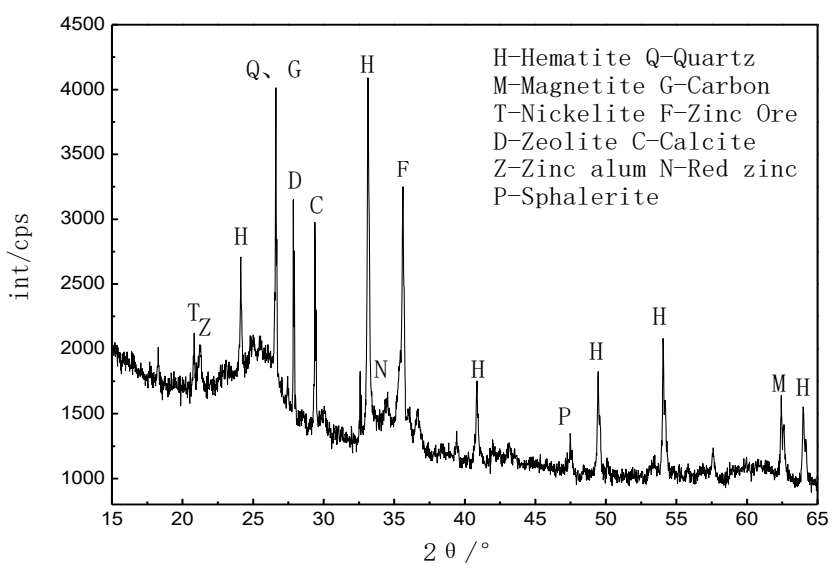

Figure 1. The XRD pattern of zinc-bearing dust sludge

Table 2. Mineral phase analysis

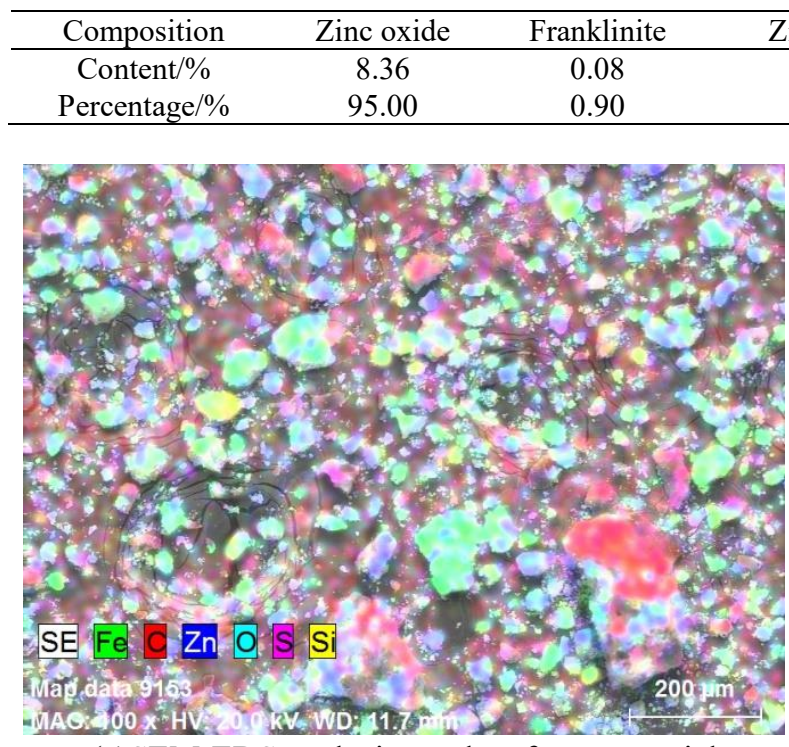

(a)SEM-EDS analysis results of raw material

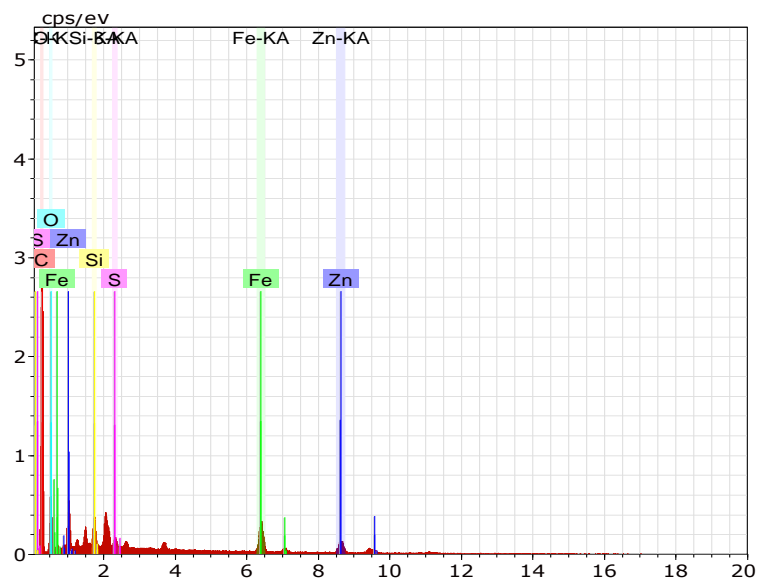

(b) EDS analysis results
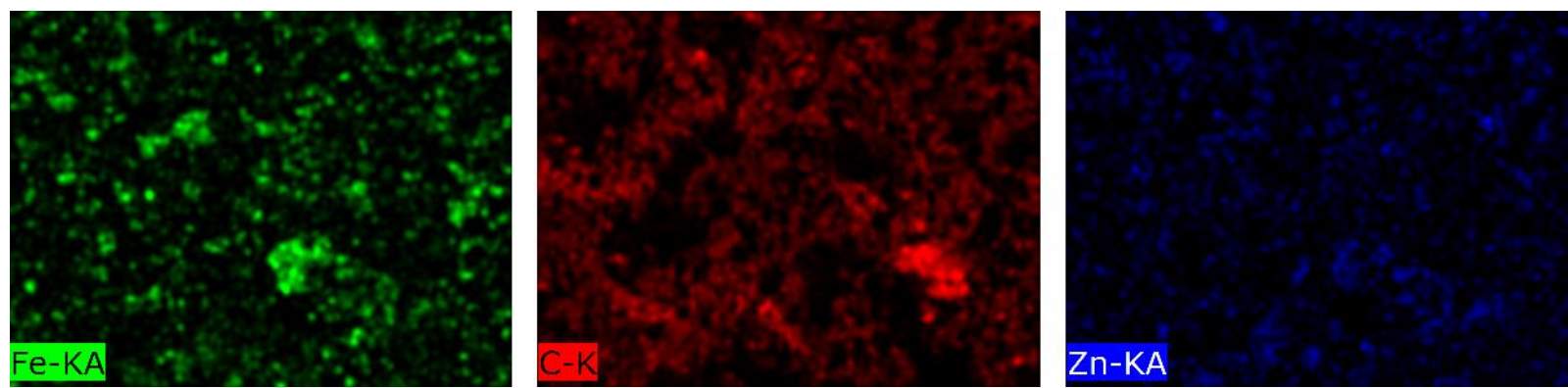

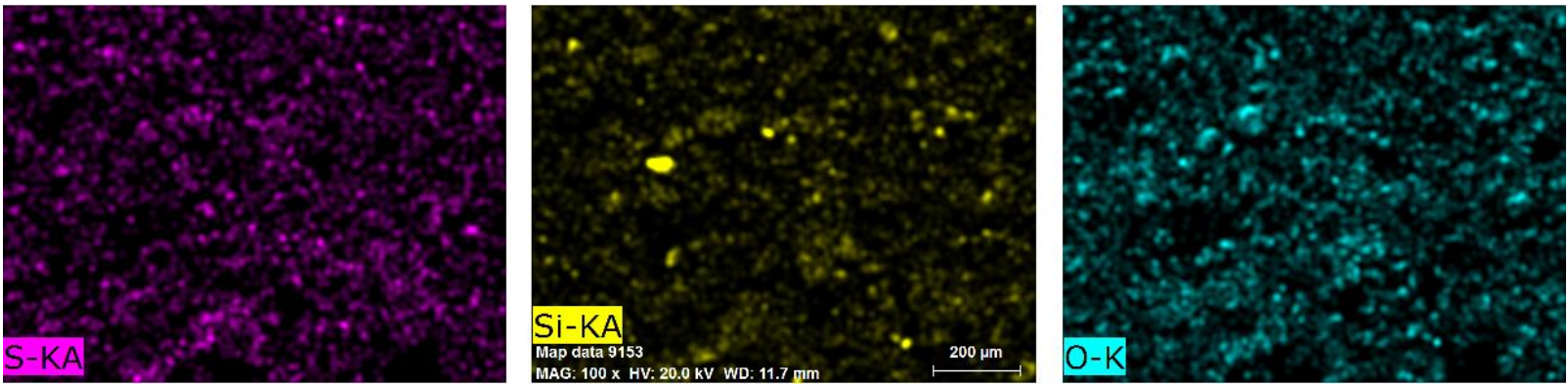

(c)Elemental surface scan results

Figure 2. Area-scan of metallurgical zinc-bearing dust sludge $(\times 100)$

An area-scan was done for the distribution of various elements in metallurgical dust sludge (Fig. 2). The raw material contains $\mathrm{Fe}, \mathrm{C}, \mathrm{Zn}, \mathrm{Si}, \mathrm{O}, \mathrm{S}$ and other elements, of which the contents of $\mathrm{Fe}, \mathrm{C}, \mathrm{Zn}$ elements are relatively rich. It is also known that the elements $\mathrm{C}, \mathrm{Si}$ and $\mathrm{Fe}$ are mainly distributed in the dust sludge particles with larger diameters, whereas the elements $\mathrm{Zn}$ and $\mathrm{S}$ in the particles with smaller diameters, the elements $\mathrm{O}$ are distributed unevenly in the dust sludge.

\subsection{Main reagents and equipment}

Reagents: Sulfuric acid (AR, 98\%)

Main instruments: SEM, EDS, XRD, HH-6 digital thermostat water bath, JJ-6S six-phase asynchronous electric mixer, 2XZ-1 rotary vane Type vacuum pump, blast drying oven, and $\mathrm{pH}$ meter.

\subsection{Experimental method}

The metallurgical zinc-bearing dust sludge was leached in a glassware-flask (multiple neck, $500 \mathrm{~mL}$ ) in a water bath with temperature controller. The accuracy of leaching temperature was $\pm 1^{\circ} \mathrm{C}$. In each experiment, $50 \mathrm{~g}$ metallurgical zinc-bearing dust sludge was added to the agitated sulfuric acid solution $(200 \mathrm{~mL})$ of a certain concentration at a required temperature. An acid resistance mechanical agitator with stirring speed of $300 \mathrm{r} / \mathrm{min}$ was applied to agitating the reaction content. The mass ratio of liquid to solid was 4 . After leaching for some time, $5 \mathrm{~mL}$ slurry was sampled with a pipette and immediately filtered after being diluted. The filtrate of the sample was analyzed for zinc content, and the fraction of zinc extraction was calculated for examining the leaching rate of the metallurgical zinc-bearing dust sludge.

\section{LEACHING THERMODYNAMICS OF ZINC- BEARING DUST SLUDGE}

\subsection{Feasibility analysis of zinc sulfate thermodynamics}

The thermodynamic analysis of the leaching process is made to determine the possibility and the directivity of the leaching reaction. The basic physical parameters of thermodynamics are derived from the thermodynamic data widely used in the world Library [13-15]. The reaction equation and Gibbs free energy involved in the leaching experiment are shown in Table 3 .

Table 3. Reaction equation and Gibbs free energy

\begin{tabular}{ccc}
\hline Number & Reaction equation & Gibbs free energy equation \\
\hline$(1)$ & $\mathrm{ZnO}(\mathrm{s})+2 \mathrm{H}^{+}=\mathrm{Zn}^{2+}+\mathrm{H}_{2} \mathrm{O}(\mathrm{L})$ & $\Delta_{\mathrm{r}} \mathrm{G}^{\theta}=-91440+85.83 \mathrm{~T}(\mathrm{~J} / \mathrm{mol})$ \\
$(2)$ & $\mathrm{CaO}(\mathrm{s})+2 \mathrm{H}^{+}=\mathrm{Ca}^{2+}+\mathrm{H}_{2} \mathrm{O}(\mathrm{L})$ & $\Delta_{\mathrm{r}} \mathrm{G}^{\theta}=-193570+22.98 \mathrm{~T}(\mathrm{~J} / \mathrm{mol})$ \\
$(3)$ & $\mathrm{Al}_{2} \mathrm{O}_{3}(\mathrm{~s})+6 \mathrm{H}^{+}=2 \mathrm{Al}^{3+}+3 \mathrm{H}_{2} \mathrm{O}(\mathrm{L})$ & $\Delta_{\mathrm{r}} \mathrm{G}^{\theta}=-243800+484.59 \mathrm{~T}(\mathrm{~J} / \mathrm{mol})$ \\
$(4)$ & $\mathrm{MgO}(\mathrm{s})+2 \mathrm{H}^{+}=\mathrm{Mg}^{2+}+\mathrm{H}_{2} \mathrm{O}(\mathrm{L})$ & $\Delta_{\mathrm{r}} \mathrm{G}^{\theta}=-150980+96.07 \mathrm{~T}(\mathrm{~J} / \mathrm{mol})$ \\
$(5)$ & $\mathrm{CaCO}_{3}(\mathrm{~s})+2 \mathrm{H}^{+}=\mathrm{Ca}^{2+}+\mathrm{H}_{2} \mathrm{O}(\mathrm{L})+\mathrm{CO}_{2}(\mathrm{~g})$ & $\Delta_{\mathrm{r}} \mathrm{G}^{\theta}=-15250-137.53 \mathrm{~T}(\mathrm{~J} / \mathrm{mol})$ \\
$(6)$ & $\mathrm{Fe}_{2} \mathrm{O}_{3}(\mathrm{~s})+6 \mathrm{H}^{+}=2 \mathrm{Fe}^{3+}+3 \mathrm{H}_{2} \mathrm{O}(\mathrm{L})$ & $\Delta_{\mathrm{r}} \mathrm{G}^{\theta}=-130300+509.45 \mathrm{~T}(\mathrm{~J} / \mathrm{mol})$ \\
$(7)$ & $\mathrm{Fe}_{3} \mathrm{O}_{4}(\mathrm{~s})+8 \mathrm{H}^{+}=2 \mathrm{Fe}^{3+}+\mathrm{Fe}^{2+}+3 \mathrm{H}_{2} \mathrm{O}(\mathrm{L})$ & $\Delta_{\mathrm{r}} \mathrm{G}^{\theta}=-211120+636.23 \mathrm{~T}(\mathrm{~J} / \mathrm{mol})$ \\
$(8)$ & $\mathrm{ZnFe}_{2} \mathrm{O}_{4}(\mathrm{~s})+4 \mathrm{H}_{2} \mathrm{SO}_{4}=\mathrm{Zn}^{2+}+\mathrm{SO}_{4}{ }^{2-}+2 \mathrm{Fe}^{3+}+4 \mathrm{H}_{2} \mathrm{O}(\mathrm{L})$ & $\Delta_{\mathrm{r}} \mathrm{G}^{\theta}=37145730-393.87 \mathrm{~T}(\mathrm{~J} / \mathrm{mol})$ \\
$(9)$ & $\mathrm{ZnFe}_{2} \mathrm{O}_{4}(\mathrm{~s})+4 \mathrm{H}_{2} \mathrm{SO}_{4}=\mathrm{Zn}^{2+}+\mathrm{SO}_{4}{ }^{2-}+\mathrm{Fe}_{2} \mathrm{O}_{3}+\mathrm{H}_{2} \mathrm{O}(\mathrm{L})$ & $\Delta_{\mathrm{r}} \mathrm{G}^{\theta}=37276030-115.58 \mathrm{~T}(\mathrm{~J} / \mathrm{mol})$
\end{tabular}

The Gibbs free energy $\Delta_{\mathrm{r}} \mathrm{G}^{\theta}$ in the reaction is calculated based on data from thermodynamics of the existence form of the reaction, and then the $\Delta_{\mathrm{r}} \mathrm{G}^{\theta}-\mathrm{T}$ of the leaching system is obtained by taking $\mathrm{T}$ as the abscissa and $\Delta_{\mathrm{r}} \mathrm{G}^{\theta}$ as the ordinate, as shown in Fig. 3.

As shown in Fig. 3, the values $\triangle_{\mathrm{r}} \mathrm{G}^{0}$ in reactions (1)-(5) are all less than zero at the leaching temperatures, and in reactions
(1), (2), (4), they do not change obviously with temperature build-ups; but it increases a little with temperature build-ups in reaction (3), and decreases a little in reaction (5). It is known from the calculation results that the reactants represented by reactions (1)-(5) are leached in the order of $\mathrm{CaO}>\mathrm{MgO}>\mathrm{ZnO}>$ $\mathrm{CaCO}_{3}>\mathrm{Al}_{2} \mathrm{O}_{3}$, while as shown in Fig. 3, the values $\triangle_{\mathrm{r}} \mathrm{G}_{\mathrm{T}}^{0}$ in reactions (6)-(7) gradually increase as the temperature climbs 
up, and are all greater than zero, which implies that the reactions hardly occur at room temperature, zinc can not be leached easily. It can be learned from Fig. 3 that the values $\triangle$ ${ }_{\mathrm{r}} \mathrm{G}_{\mathrm{T}}^{0}$ in reactions (8)-(9) are far greater than zero, which indicates that the reactions will occur more difficultly under common leaching conditions. Consequently, the reactants represented by reactions (6)-(9) are leached in the following order: $\mathrm{Fe}_{2} \mathrm{O}_{3}>\mathrm{Fe}_{3} \mathrm{O}_{4}>\mathrm{ZnFe}_{2} \mathrm{O}_{4}$. It further turns out that for Metallurgical Zinc-Bearing Dust Sludge, it is feasible to leach zinc at a room temperature, where a large mass of zinc can be separated with irons left in the slag.

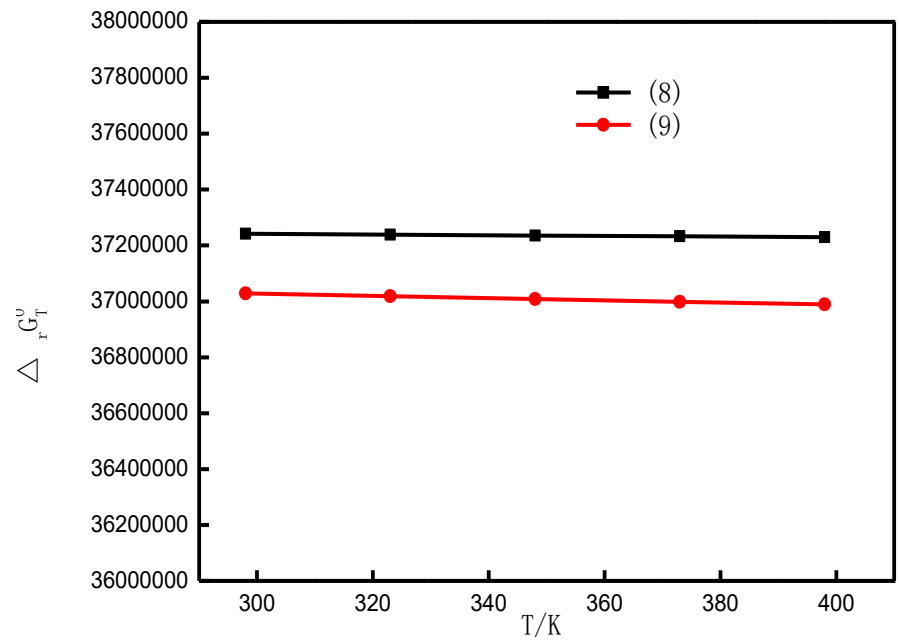

Figure 3. $\triangle_{\mathrm{r}} \mathrm{G}^{0} \mathrm{~T}-\mathrm{T}$ map for leaching system

Table 4. $\mathrm{Zn}-\mathrm{Fe}-\mathrm{H}_{2} \mathrm{O}$ system potential-pH relationship

\begin{tabular}{ccc}
\hline Number & Reaction equation & Potential-pH balance formula \\
\hline$(1)$ & $\mathrm{Fe}^{3+}+\mathrm{e}=\mathrm{Fe}^{2+}$ & $\varphi=0.7710+0.0591 \lg \alpha_{F e^{3+}}-0.0591 \lg \alpha_{F e^{2+}}$ \\
$(2)$ & $\mathrm{Fe}_{2} \mathrm{O}_{3}+6 \mathrm{H}^{+}=2 \mathrm{Fe}^{3+}+3 \mathrm{H}_{2} \mathrm{O}$ & $p H=-0.2407-0.3333 \lg \alpha_{\mathrm{Fe}^{3+}}$ \\
$(3)$ & $\mathrm{Fe}_{2} \mathrm{O}_{3}+6 \mathrm{H}^{+}+2 \mathrm{e}=2 \mathrm{Fe}^{2+}+3 \mathrm{H}_{2} \mathrm{O}$ & $\varphi=0.7279-0.1773 p H-0.0591 \lg \alpha_{\mathrm{Fe}^{2+}}$ \\
$(4)$ & $\mathrm{ZnO} \cdot \mathrm{Fe}_{2} \mathrm{O}_{3}+2 \mathrm{H}^{+}=\mathrm{Zn}^{2+}+\mathrm{H}_{2} \mathrm{O}+\mathrm{Fe}_{2} \mathrm{O}_{3}$ & $p H=3.3754-0.5000 \lg \alpha_{\mathrm{Zn}^{2+}}$ \\
$(5)$ & $\mathrm{ZnO} \cdot \mathrm{Fe}_{2} \mathrm{O}_{3}+8 \mathrm{H}^{+}+2 \mathrm{e}=\mathrm{Zn}^{2+}+4 \mathrm{H}_{2} \mathrm{O}+2 \mathrm{Fe}^{2+}$ & $\varphi=0.9275-0.2364 p H-0.0295 \lg \alpha_{\mathrm{Zn}^{2+}}-0.0591 \lg \alpha_{\mathrm{Fe}^{2+}}$ \\
$(6)$ & $\mathrm{Fe}^{2+}+2 \mathrm{e}=\mathrm{Fe}$ & $\varphi=-0.441+0.0295 \lg \alpha_{\mathrm{Fe}^{2+}}$ \\
$(7)$ & $\mathrm{ZnO} \cdot \mathrm{Fe}_{2} \mathrm{O}_{3}+6 \mathrm{H}^{+}+6 \mathrm{e}=\mathrm{ZnO}+3 \mathrm{H}_{2} \mathrm{O}+2 \mathrm{Fe}$ & $\varphi=-0.0986-0.0591 p H$ \\
$(8)$ & $2 \mathrm{H}^{+}+2 \mathrm{e}=\mathrm{H}_{2}$ & $\varphi=-0.0591 p H$ \\
$(9)$ & $\mathrm{O}_{2}+4 \mathrm{H}^{+}+4 \mathrm{e}=2 \mathrm{H}_{2} \mathrm{O}$ & $\varphi=1.2292-0.0591 p H$
\end{tabular}

\section{$3.2 \varphi-p H$ dominant areas of different systems}

Zinc-bearing dust sludge contains some zinc and iron phases, mainly including $\mathrm{ZnO}, \mathrm{ZnS}, \mathrm{ZnFe}_{2} \mathrm{O}_{4}, \mathrm{Fe}_{2} \mathrm{O}_{3}$ and $\mathrm{Fe}_{3} \mathrm{O}_{4}$. The $\varphi$-pH dominant area maps plotted for $\mathrm{Zn}-\mathrm{Fe}-\mathrm{H}_{2} \mathrm{O}$, Zn-S$\mathrm{H}_{2} \mathrm{O}$ systems are computed, so do the $\lg [\mathrm{C}]-\mathrm{pH}$ maps for $\mathrm{ZnO}$, $\mathrm{Fe}_{2} \mathrm{O}_{3}, \mathrm{Fe}(\mathrm{OH})_{2}, \mathrm{Fe}(\mathrm{OH})_{3}$, for the purpose of analyzing the thermodynamic behavior of sulfuric acid leaching from metallurgical zinc-bearing dust sludge.

(1) $\mathrm{Zn}-\mathrm{Fe}-\mathrm{H}_{2} \mathrm{O}$ system $\varphi$-pH area maps

In $\mathrm{Zn}-\mathrm{Fe}-\mathrm{H}_{2} \mathrm{O}$ system, there is a compound $\mathrm{ZnFe}_{2} \mathrm{O}_{4}$. When the temperature is $25^{\circ} \mathrm{C}$, an equilibrium reaction occurs in such system on the principle of simultaneous equilibrium and electroneutrality [16-19], as shown in Fig. 4.

The $\varphi-\mathrm{pH}$ dominant area map of $\mathrm{Zn}-\mathrm{Fe}-\mathrm{H}_{2} \mathrm{O}$ system is calculated by FactSage [20], as shown in Fig.4. It can be seen from Fig. 4, as the concentrations of zinc and iron ions in the solution increase, and each component in solution does not change, the size of the dominant area is subjected to change with the solution $\mathrm{pH}$. The pole potential used for the formation of target component $\mathrm{Zn}^{2+}$ gets lower and lower, which is more conducive to leaching. At room temperature, the control potential is greater than $0.77 \mathrm{~V}$, and the $\mathrm{pH}$ is less than -0.24 , the zinc and iron will enter the solution in the forms of $\mathrm{Zn}^{2+}$, $\mathrm{Fe}^{3+}$ respectively, until the $\mathrm{Zn}^{2+}, \mathrm{Fe}^{3+}$ activities reach 1 . When the potential and $\mathrm{pH}$ are controlled within II, the zinc will enter the solution selectively, while the iron remains in the slag in the form of $\mathrm{Fe}_{2} \mathrm{O}_{3}$, achieving the goal of the separation of the two while leaching. When the potential, $\mathrm{pH}$ are controlled within IV area, in the presence of appropriate reduction agent and $\mathrm{pH}$, they can enter the solution in the forms of $\mathrm{Zn}^{2+}$ and $\mathrm{Fe}^{2+}$. 


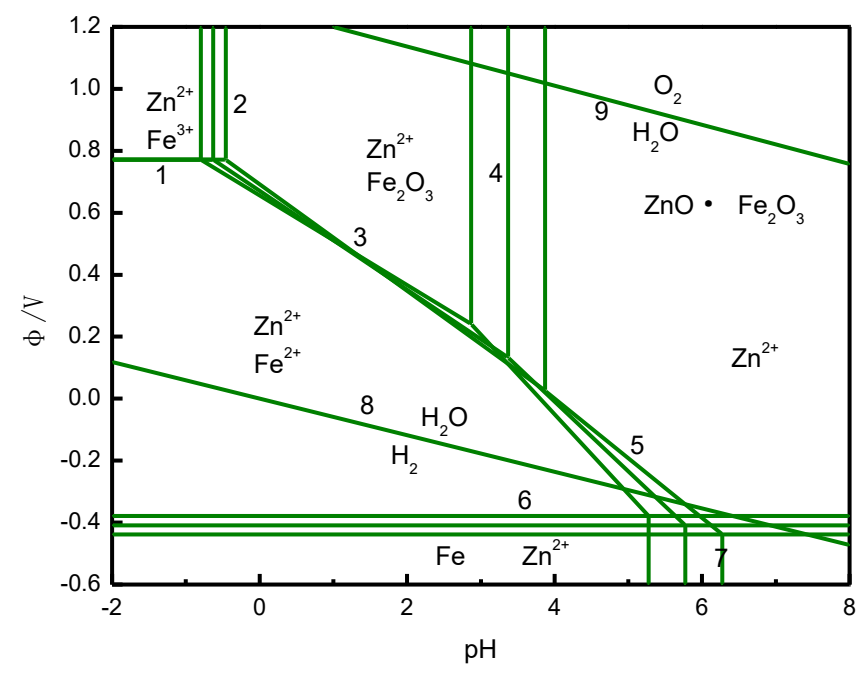

Figure 4. $\varphi$ - $\mathrm{pH}$ figure of $\mathrm{Zn}-\mathrm{Fe}-\mathrm{H}_{2} \mathrm{O}$ under different ion concentration of iron and zinc

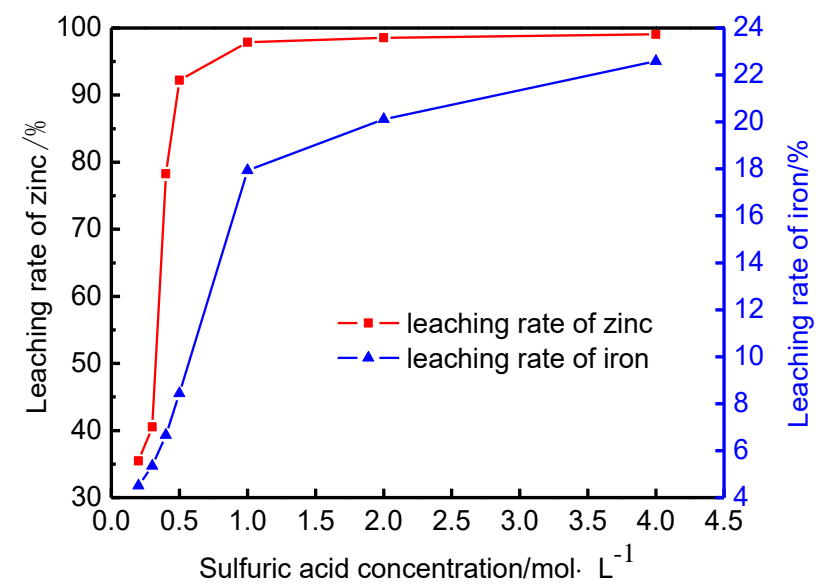

Figure 5. Leaching of the zinc-bearing dust under different sulfuric acid concentration

Figure 5 shows the effect of different sulfuric acid concentration on the leaching rate of zinc and iron in zincbearing dust. As can be seen from the figure, the leaching rate of zinc and iron increases with the increase of sulfuric acid concentration. When sulfuric acid concentration is increased from $0.2 \mathrm{~mol} / \mathrm{L}$ increased to $0.5 \mathrm{~mol} / \mathrm{L}$, the leaching rate of zinc reached $94.00 \%$. With the continuous increase of sulfuric acid concentration, the leaching rate of iron continued to increase, while the leaching rate of zinc increased slowly, which may be due to the formation of dissolved iron The colloidal zinc adsorption enhanced, so that zinc failed to enter the leachate, and remain in the leaching residue, taking into account the high concentration of sulfuric acid, dissolved $\mathrm{Fe}^{2+}$ increase, will make subsequent leachate treatment more difficult, so you must control the sulfuric acid concentration.

(2) Potential-pH of $\mathrm{Zn}-\mathrm{S}-\mathrm{H}_{2} \mathrm{O}$ system

In the $\mathrm{Zn}-\mathrm{S}-\mathrm{H}_{2} \mathrm{O}$ system, there is a compound $\mathrm{ZnS}$. When the temperature is $25^{\circ} \mathrm{C}$, an equilibrium reaction occurs in such a system as shown in Table 5 . $\mathrm{Zn}-\mathrm{S}-\mathrm{H}_{2} \mathrm{O}$ system potential-pH obtained according to the reaction is shown in Fig. 6.

As learned from Fig. 6, for $\mathrm{ZnS}$, the $\mathrm{pH}$ required for simple acid leaching is very low, i.e. -1.585. In fact, it is not feasible. For $\mathrm{ZnS}$, the atmospheric oxygen-enriched leaching or the pressure acid leaching is generally adopted. When sulfuric acid is used as a leaching agent to extract zinc from zincbearing dust sludge, zinc sulfide gets difficult to be leached.

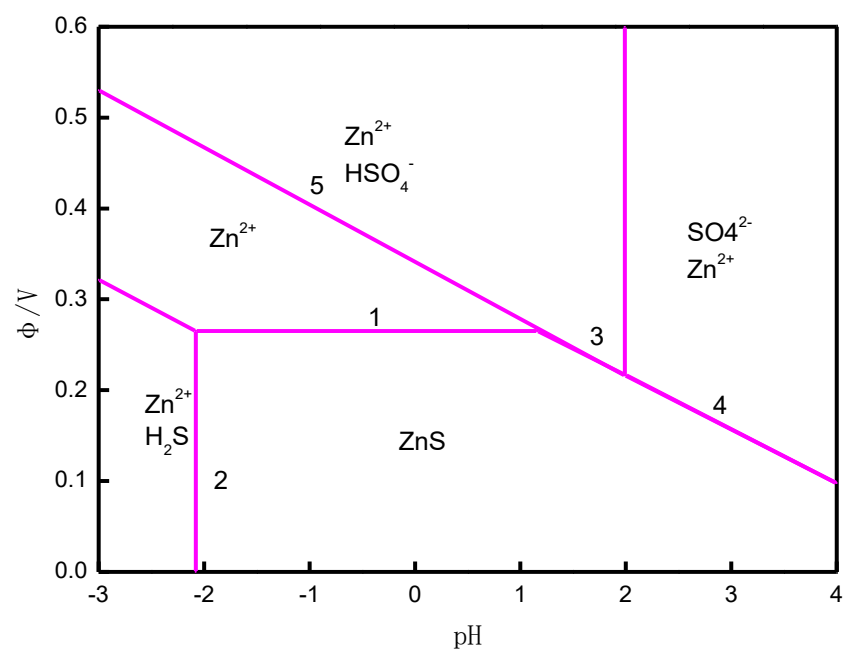

Figure 6. $\varphi$ - $\mathrm{pH}$ figure of $\mathrm{Zn}-\mathrm{S}-\mathrm{H}_{2} \mathrm{O}$ under different temperature $(\mathrm{ZnS})$

Table 5. $\mathrm{Zn}-\mathrm{S}-\mathrm{H}_{2} \mathrm{O}$ system potential-pH relationship

\begin{tabular}{ccc}
\hline Number & Reaction equation & Potential-pH balance formula \\
\hline$(1)$ & $\mathrm{Zn}^{2+}+\mathrm{S}+2 \mathrm{e}=\mathrm{ZnS}$ & $\varphi=0.265+0.0295 \lg \alpha_{\mathrm{Zn}^{2+}}$ \\
$(2)$ & $\mathrm{ZnS}+2 \mathrm{H}^{+}=\mathrm{Zn}^{2+}+\mathrm{H}_{2} \mathrm{~S}$ & $p H=-2.08-0.5 \lg \mathrm{H}_{2} S-0.5 \lg \alpha_{\mathrm{Zn}^{2+}}$ \\
$(3)$ & $\mathrm{Zn}^{2+}+\mathrm{HSO}_{4}{ }^{-}+7 \mathrm{H}^{+}+8 \mathrm{e}=\mathrm{ZnS}+4 \mathrm{H}_{2} \mathrm{O}$ & $\varphi=0.320-0.0517 p H+0.0074 \lg \alpha_{\mathrm{Zn}^{2+}}+0.0074 \lg \alpha_{H S O_{4}^{-}}$ \\
$(4)$ & $\mathrm{Zn}^{2+}+\mathrm{SO}_{4}{ }^{2-}+8 \mathrm{H}^{+}+8 \mathrm{e}=\mathrm{ZnS}+4 \mathrm{H}_{2} \mathrm{O}$ & $\varphi=0.334-0.0591 p H+0.0074 \lg \alpha_{\mathrm{Zn}^{2+}}+0.0074 \lg \alpha_{S O_{4}^{2-}}$ \\
$(5)$ & $\mathrm{Zn}(\mathrm{OH})_{2}+\mathrm{SO}_{4}{ }^{2-}+10 \mathrm{H}^{+}+8 \mathrm{e}=\mathrm{ZnS}+6 \mathrm{H}_{2} \mathrm{O}$ & $\varphi=0.42-0.074 p H+0.0074 \lg \alpha_{S_{4}^{2-}}$ \\
\hline
\end{tabular}

\section{$3.3 \lg [\mathrm{C}]-\mathrm{pH}$ map in sulfuric acid zinc-leaching system}

(1) $\lg [\mathrm{C}]-\mathrm{pH}$ map in $\mathrm{ZnO}$

Since $\mathrm{ZnO}$ is easily to form the hydroxyl complex ions in aqueous solution, the $\lg [\mathrm{C}]-\mathrm{pH}$ map of $\mathrm{ZnO}$ is affected to a large extent by the reactants from hydroxyl complex. There is an equilibrium as shown in Table 6 , while $\lg [\mathrm{C}]-\mathrm{pH}$ map of
$\mathrm{ZnO}$ is available. $\mathrm{C}$ in Fig. 7 represents the total concentration of zinc ions at different $\mathrm{pHs}$.

In Fig. 7, the dotted lines in purple surround a stable area for the $\mathrm{ZnO}$ solid phase, whose boundary lines shows the relationship of the total concentration of $\mathrm{Zn}^{2+}$ as a function of $\mathrm{pHs}$ in the system. It is known from the solubility curve of zinc oxide that the equilibrium concentration of metal ion $\mathrm{Zn}^{2+}$ in the solution has a tendency to first climb down and then up 
with the increase of $\mathrm{pH}$ value since $\mathrm{ZnO}$ is an amphoteric oxide and easily forms hydroxyl complex ions $\left(\mathrm{Zn}(\mathrm{OH})^{+}\right.$, $\left.\mathrm{Zn}(\mathrm{OH})_{3}{ }^{-}, \mathrm{Zn}(\mathrm{OH})_{4}{ }^{2-}\right)$ in aqueous solution. Under neutral or weak alkaline conditions, the metals present in the form of $\mathrm{Zn}^{2+}$ in the solution. As $\mathrm{pH}$ value is on the rise, various complex ions formed with $\mathrm{OH}^{-}$also increase. It follows that the total concentration of metal ions in solution tends to increase when the $\mathrm{pH}$ value is higher. For this reason, sulfuric acid is taken as a leaching agent, the $\mathrm{pH}$ should be controlled within a certain range in order to facilitate the dissolution of zinc oxide, avoiding the fact that the leaching rate is affected by the generation of complex ions.

Table 6. $\mathrm{ZnO}$ solubility

\begin{tabular}{ccc}
\hline Reaction equation & Balance equation & Equilibrium constant \\
\hline $\mathrm{ZnO}+2 \mathrm{H}^{+}=\mathrm{Zn}^{2+}+\mathrm{H}_{2} \mathrm{O}$ & $\lg \left[\mathrm{Zn}^{2+}\right]=11.2-2 p H$ & $\lg \mathrm{S}_{\mathrm{S} 0}=11.2$ \\
$\mathrm{ZnO}+\mathrm{H}^{+}=\mathrm{ZnOH}^{+}$ & $\lg \left[\mathrm{ZnOH}^{+}\right]=2.2-p H$ & $\lg \mathrm{S}_{\mathrm{S} 1}=2.2$ \\
$\mathrm{ZnO}+2 \mathrm{H}_{2} \mathrm{O}=\mathrm{Zn}(\mathrm{OH})_{3}{ }^{-}+\mathrm{H}^{+}$ & $\lg \left[\mathrm{Zn}(\mathrm{OH})_{3}^{-}\right]=-16.9+p H$ & $\lg \mathrm{S}_{\mathrm{S} 2}=-16.9$ \\
$\mathrm{ZnO}+3 \mathrm{H}_{2} \mathrm{O}=\mathrm{Zn}(\mathrm{OH})_{4}{ }^{2-}+2 \mathrm{H}^{+}$ & $\lg \left[\mathrm{Zn}(\mathrm{OH})_{4}^{2-}\right]=-29.7+2 p H$ & $\lg \mathrm{K}_{\mathrm{S} 3}=-29.7$ \\
\hline
\end{tabular}

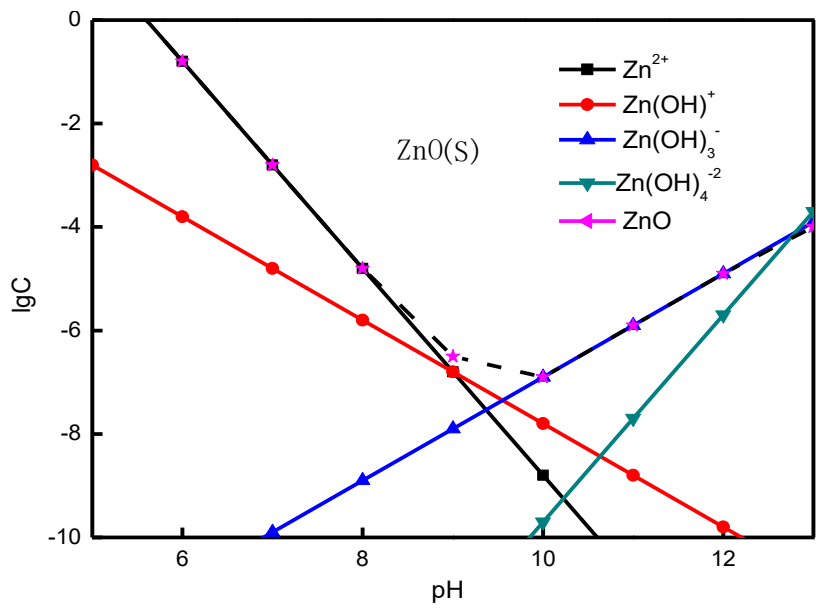

Figure 7. Solubility figure of $\mathrm{ZnO}$

(2) $\lg [\mathrm{C}]-\mathrm{pH}$ map of $\mathrm{Fe}_{2} \mathrm{O}_{3}$

$\mathrm{Fe}_{2} \mathrm{O}_{3}$ runs the following reaction in aqueous solution. From the following equilibrium, both sides take the logarithms to get the relationship between the concentration of each component and $\mathrm{pH}$ value, as shown in Table 7.

$\lg [\mathrm{C}]-\mathrm{pH}$ map of $\mathrm{Fe}_{2} \mathrm{O}_{3}$ is plotted according to the equation shown in Table 7. There are several dotted yellow lines in Fig. 8 which constitute a stable area for $\mathrm{Fe}_{2} \mathrm{O}_{3}$ solid phase. This stable area has some borderlines that represent the relationship between the total iron ion concentration at different $\mathrm{pHs}$ in this system. It is obvious from the solubility curve of $\mathrm{Fe}_{2} \mathrm{O}_{3}$ that the equilibrium concentration of iron ions in solution decreases first and then increases as $\mathrm{pH}$ value is on the rise since $\mathrm{Fe}_{2} \mathrm{O}_{3}$ is easy to form hydroxyl complex ion $\left(\mathrm{FeOH}^{2+}\right.$, $\left.\mathrm{Fe}(\mathrm{OH})^{2+}, \mathrm{Fe}(\mathrm{OH})^{4-}\right)$. The $\mathrm{pH}$ required for the dissolution of $\mathrm{Fe}_{2} \mathrm{O}_{3}$ is low even in a strong acid environment. It is therefore certain that when sulfuric acid is used as a leaching agent, it is not easy to leach $\mathrm{Fe}_{2} \mathrm{O}_{3}$. Only when the $\mathrm{pH}$ is controlled in a certain scope can zinc be leached, while the leaching of iron is inhibited.

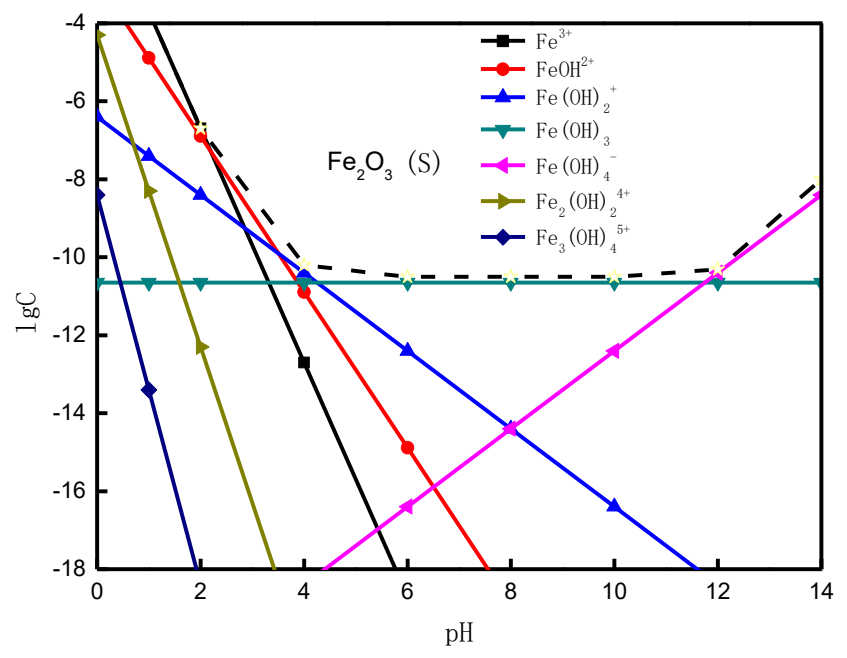

Figure 8. Solubility figure of $\mathrm{Fe}_{2} \mathrm{O}_{3}$

Table 7. $\mathrm{Fe}_{2} \mathrm{O}_{3}$ solubility

\begin{tabular}{ccc}
\hline Reaction equation & Balance equation & Equilibrium constant \\
\hline$\frac{1}{2} \mathrm{Fe}_{2} \mathrm{O}_{3}(S)+\frac{3}{2} \mathrm{H}_{2} \mathrm{O}=\mathrm{Fe}^{3+}+3 \mathrm{OH}^{-}$ & $\lg \left[\mathrm{Fe}^{3+}\right]=-0.7-3 \mathrm{pH}$ & $\lg K_{s p}=-42.7$ \\
$\mathrm{Fe}^{3+}+\mathrm{OH}^{-}=\mathrm{FeOH}^{2+}$ & $\lg \left[\mathrm{FeOH}^{2+}\right]=-2.89-2 \mathrm{pH}$ & $\lg K_{1}=11.81$ \\
$\mathrm{Fe}^{3+}+2 \mathrm{OH}^{-}=\mathrm{Fe}(\mathrm{OH})_{2}^{+}$ & $\lg \left[\mathrm{Fe}(\mathrm{OH})^{2+}\right]=-6.4-\mathrm{pH}$ & $\lg K_{2}=22.3$ \\
$\mathrm{Fe}^{3+}+3 \mathrm{OH}^{-}=\mathrm{Fe}(\mathrm{OH})_{3}$ & $\lg \left[\mathrm{Fe}(\mathrm{OH})_{3}\right]=-10.65$ & $\lg K_{3}=32.05$ \\
$\mathrm{Fe}^{3+}+4 \mathrm{OH}^{-}=\mathrm{Fe}(\mathrm{OH})_{4}^{-}$ & $\lg \left[\mathrm{Fe}(\mathrm{OH})^{4-}\right]=-22.4+\mathrm{pH}$ & $\lg K_{4}=34.3$ \\
$2 \mathrm{Fe}^{3+}+2 \mathrm{OH}^{-}=\mathrm{Fe}_{2}(\mathrm{OH})_{2}^{4+}$ & $\lg \left[\mathrm{Fe}_{2}(\mathrm{OH})_{2}{ }^{4+}\right]=-4.30-4 \mathrm{pH}$ & $\lg K_{5}=25.15$ \\
$3 \mathrm{Fe}^{3+}+4 \mathrm{OH}^{-}=\mathrm{Fe}_{3}(\mathrm{OH})_{4}^{5+}$ & $\lg \left[\mathrm{Fe}_{3}(\mathrm{OH})_{4}{ }^{5+}\right]=-8.40-5 \mathrm{pH}$ & $\lg K_{6}=49.7$ \\
\hline
\end{tabular}


(3) $\mathrm{Fe}(\mathrm{OH})_{2}, \mathrm{Fe}(\mathrm{OH})_{3} \lg [\mathrm{C}]-\mathrm{pH}$

When there are $\mathrm{Fe}(\mathrm{OH})_{2}, \mathrm{Fe}_{2} \mathrm{O}_{3}, \mathrm{Fe}(\mathrm{OH})_{3}$ in solution, based on the Gibbs free energy in the standard state of each substance in the solution, an equilibrium expression between different substances is available from the reaction equation, as shown in Table 8 .

The $\mathrm{Fe}(\mathrm{OH})_{2} \lg [\mathrm{C}]-\mathrm{pH}$ is shown in Fig. 9. If $\mathrm{pH}<10, \mathrm{Fe}^{2+}$ appears in solution. As the $\mathrm{pH}$ increases, the $\mathrm{Fe}(\mathrm{OH})_{2}$ is gradually precipitated in solution. When $\mathrm{pH}$ value continues to increase, the precipitation of $\mathrm{Fe}(\mathrm{OH})_{2}$ is then gradually dissolved into complex ions $\mathrm{HFeO}_{2}$ -

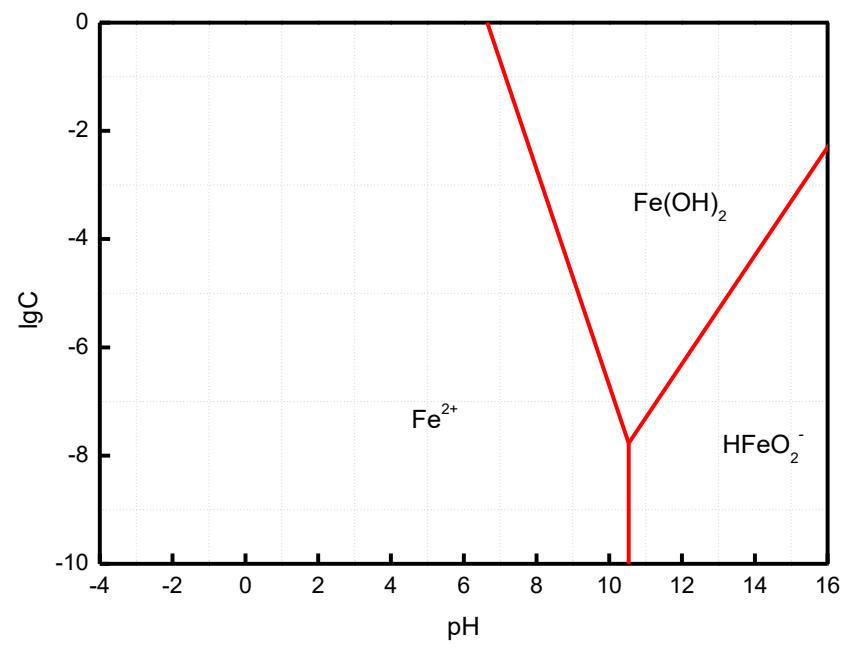

Figure 9. Solubility figure of $\mathrm{Fe}(\mathrm{OH})_{2}$ under different $\mathrm{pH}$
$\mathrm{Fe}_{2} \mathrm{O}_{3}$ and $\mathrm{Fe}(\mathrm{OH})_{3} \lg [\mathrm{C}]-\mathrm{pH}$ maps obtained according to the above equilibrium reaction are shown in Fig. 10. As can be seen, when the $\mathrm{pH}$ value is low, $\mathrm{Fe}^{2+}, \mathrm{Fe}_{2} \mathrm{O}_{3}$ and complex ions $\mathrm{FeOH}^{2+}, \mathrm{Fe}(\mathrm{OH})^{2+}$ may appear in solution. If $\mathrm{pH}>8$, stable $\mathrm{Fe}(\mathrm{OH})_{3}$ precipitation is formed in solution. In the subsequent leachate treatment, add an proper amount of oxidant such as potassium permanganate, manganese dioxide, hydrogen peroxide and the like to the solution to oxidize $\mathrm{Fe}^{2+}$ into $\mathrm{Fe}^{3+}$, and then add $\mathrm{NaOH}$ to turn $\mathrm{Fe}^{3+}$ into $\mathrm{Fe}(\mathrm{OH})_{3}$ sediment, thus achieve the purpose of removing iron, so that the leachate has been purified, more importantly, it is more advantage for the subsequent treatment of leachate.

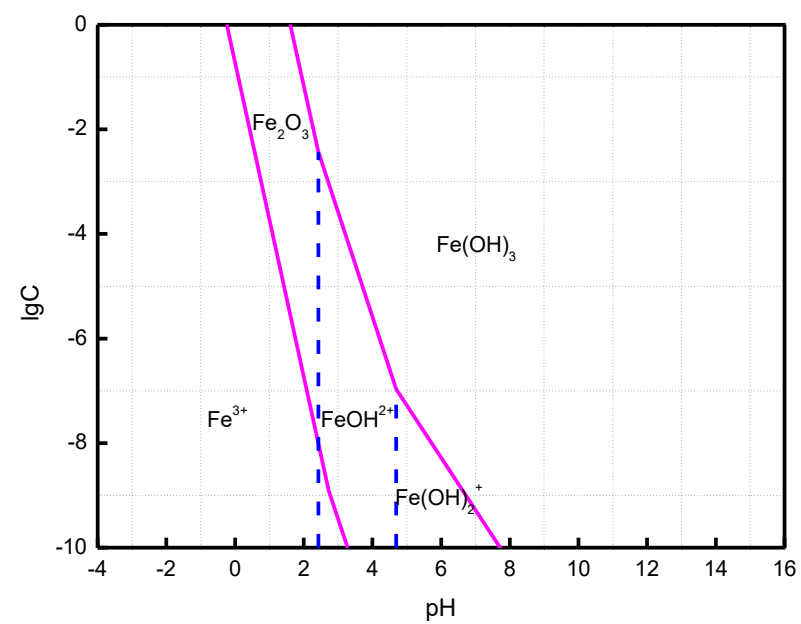

Figure 10. Solubility figure of $\mathrm{Fe}_{2} \mathrm{O}_{3}$ and $\mathrm{Fe}(\mathrm{OH})_{3}$

Table 8. $\mathrm{Fe}(\mathrm{OH})_{2}, \mathrm{Fe}(\mathrm{OH})_{3}$ solubility

\begin{tabular}{ccc}
\hline Number & Reaction equation & Balance expression \\
\hline$(1)$ & $\mathrm{Fe}^{2+}+\mathrm{H}_{2} \mathrm{O}=\mathrm{FeO}+2 \mathrm{H}^{+}$ & $\lg \left[\mathrm{Fe}^{2+}\right]=13.29-2 p H$ \\
$(2)$ & $\mathrm{FeO}+\mathrm{H}_{2} \mathrm{O}=\mathrm{HFeO}_{2}{ }^{-}+\mathrm{H}^{+}$ & $\lg \left[\mathrm{HFeO}_{2}^{-}\right]=-18.30+p H$ \\
$(3)$ & $\mathrm{Fe}^{2+}+2 \mathrm{H}_{2} \mathrm{O}=\mathrm{HFeO}_{2}{ }^{-}+3 \mathrm{H}^{+}$ & $p H=10.53$ \\
$(4)$ & $2 \mathrm{Fe}^{3+}+3 \mathrm{H}_{2} \mathrm{O}=\mathrm{Fe}_{2} \mathrm{O}_{3}+6 \mathrm{H}^{+}$ & $\lg \left[\mathrm{Fe}^{3+}\right]=-0.72-3 p H$ \\
$(5)$ & $\mathrm{Fe}^{3+}+3 \mathrm{H}_{2} \mathrm{O}=\mathrm{Fe}(\mathrm{OH})_{3}+3 \mathrm{H}^{+}$ & $\lg \left[\mathrm{Fe}^{3+}\right]=4.84-3 p H$ \\
$(6)$ & $2 \mathrm{FeOH}^{2+}+\mathrm{H}_{2} \mathrm{O}=\mathrm{Fe}_{2} \mathrm{O}_{3}+4 \mathrm{H}^{+}$ & $\lg \left[\mathrm{FeOH}^{2+}\right]=-3.45-2 p H$ \\
$(7)$ & $2 \mathrm{FeOH}^{2+}+\mathrm{H}_{2} \mathrm{O}=\mathrm{Fe}^{3}\left(\mathrm{OH}_{3}+\mathrm{H}^{+}\right.$ & $\lg \left[\mathrm{FeOH}^{2+}\right]=2.41-2 p H$ \\
$(8)$ & $\mathrm{Fe}^{3+}+\mathrm{H}_{2} \mathrm{O}=\mathrm{FeOH}{ }^{2+}+\mathrm{H}^{+}$ & $\mathrm{pH}=2.43$ \\
$(9)$ & $\mathrm{FeOH}^{2+}+\mathrm{H}_{2} \mathrm{O}=\mathrm{Fe}(\mathrm{OH})^{2+}+\mathrm{H}^{+}$ & $\mathrm{pH}=4.69$ \\
\hline
\end{tabular}

\section{CONCLUSION}

(1) In the $\mathrm{Zn}-\mathrm{Fe}-\mathrm{H}_{2} \mathrm{O}$ system, the aggregation state of the dissolved components remains unchanged as the concentration of $\mathrm{Zn}^{2+}$ increases, but the potential of forming $\mathrm{Zn}^{2+}$ is gradually decreases. This is extremely conducive to the leaching reaction. In the potential-pH diagram of $\mathrm{Fe}-\mathrm{H}_{2} \mathrm{O}$ system, it is controlled within certain potential and $\mathrm{pH}$ to constitute a stable area required for leaching and leachate purification. When the potential and $\mathrm{pH}$ are controlled in different ranges, $\mathrm{Zn}$ and $\mathrm{Fe}$ are separated.

(2) From the $\mathrm{ZnO}, \mathrm{Fe}_{2} \mathrm{O}_{3} \lg [\mathrm{C}]-\mathrm{pH}$, it can be seen that when sulfuric acid is used as the leaching agent, $\mathrm{Fe}_{2} \mathrm{O}_{3}$ is leached more difficultly. PH must be controlled within about 4 in order to achieve an easy dissolution of zinc oxide while inhabiting Fe leaching.

(3) It has proved by comparison of $\lg [\mathrm{C}]-\mathrm{pH}$ maps of $\mathrm{Fe}(\mathrm{OH})_{2}, \mathrm{Fe}(\mathrm{OH})_{3}$ that in the subsequent leachate treatment, after adding the proper amount of oxidant to the solution to oxidize $\mathrm{Fe}^{2+}$ into $\mathrm{Fe}^{3+}$, and then $\mathrm{NaOH}$ to make $\mathrm{Fe}^{3+}$ form $\mathrm{Fe}(\mathrm{OH})_{3}$ sediment, the iron is then removed from the solution.

(4) According to the basic principles of thermodynamics, the feasibility of leaching zinc sulfate and the stable region required for subsequent leachate purification were theoretically verified by plotting the $\varphi-\mathrm{pH}$ dominant region diagram and $\mathrm{lg}[\mathrm{C}]-\mathrm{pH}$ diagram of different systems. The research results have important theoretical significance for the 
leaching and purification process of alkali leachingelectrolysis process.

\section{ACKNOWLEDGEMENTS}

This work is financially supported by the Natural Science Foundation of Hebei Province(E2018209085).

\section{REFERENCES}

[1] Zhuang CL, Liu JH, Cui H, Liu ST, Attorre DR, Hunt J. (2011). Basicproperties and comprehensive utilization of iron-containing sludge $\&$ dust in the steelmaking process. Journal of University of Science and Technology Beijing 33(11): 185-193.

[2] Wang F, Zhang JL, Mao R, Liu ZJ. (2016). Bonding mechanism and strength deterioration of self-reducing briquettes made from iron-bearing dust and sludge. Journal of Central South University (Science and Technology) 47(2): 367-372. https://doi.org/ 10.11817/j.issn.1672-7207.2016.02.002

[3] Virolainen S, Salmimies R, Hasan M, Häkkinen A, Sainio T. (2013). Recovery of valuable metals from argon oxygen decarburization (AOD) dusts by leaching. Filtration and Solvent Extraction, Hydrometallurgy 140(11): 181-189. https://doi.org/ 10.1016/j.hydromet.2013.10.002

[4] Joldeş NT, Gyenge C, Achimaș G. (2017). The waste and the environment. Academic Journal of Manufacturing Engineering 15(2): 111-114.

[5] Wu ZJ, Huang W, Cui KK, Gao ZF, Wang P. (2014). Sustainable synthesis of metals-doped zno nanoparticles from zinc-bearing dust for photodegradation of phenol. Journal of Hazardous Materials 278(8): 91-99. https://doi.org/ 10.1016/j.jhazmat.2014.06.001

[6] Steer JM, Griffiths AJ. (2013). Investigation of carboxylic acids and non-aqueous solvents for the selective leaching of zinc from blast furnace dust slurry. Hydrometallurgy 11(140): 34-41. https://doi.org/ 10.1016/j.hydromet.2013.08.011

[7] Kul M, Oskay KO, Şimşir M, Sübütay H, Kirgezen H. (2015). Optimization of selective leaching of $\mathrm{zn}$ from electric arc furnace steelmaking dust using response surface methodology. Transactions of Nonferrous Metals Society of China 25(8): 2753-2762. https://doi.org/ $10.1016 /$ S1003-6326(15)63900-0
[8] Li Q, Zhang B, Min XB, Shen WQ. (2013). Acid leaching kinetics of zinc plant purification residue. Transactions of Nonferrous Metals Society of China 23(9): 2786-2791. https://doi.org/ 10.1016/S10036326(13)62798-3

[9] Karayannis V, Domopoulou A, Baklavaridis A, Kyratsis P. (2016). Ceramic processing via microwave irradiation. Academic Journal of Manufacturing Engineering 14(4): 54-61.

[10] Yang SH, Li H, Sun YW, Chen YM, Tang CB, He J. (2016). Leaching kinetics of zincsilicate in ammonium chloride solution. Transactions of Nonferrous Metals Society of China 26(6): 1688-1695. https://doi.org/ 10.1016/S1003-6326(16)64278-4

[11] Bai SP. (2007). Study on efficient utilization of bf gas slime Chongqing: chongqing university.

[12] Ding ZY, Chen QY, Yin ZL. (2013). Predominance diagrams for zn(ii)-nh3-cl-h2o system. Transactions of Nonferrous Metals Society of China 23(3): 832-840.

[13] Barin I, Platzki G. (1995). Thermochemical data of pure substances, Parts I. and II, Weinheim: Vch Verlagsgesellschaft mbH, pp. 1-2. https://doi.org/ 10.1002/9783527619825

[14] Knacke O, Kubaschewski O, Hesselman K. (1991). Thermochemical properties of inorganic substances, 2nd ed.berlin: springer-verlag, 1991: 1114-2412.

[15] Melik B, Iezid M, Goumeidane F, Legouera M. (2017). Structure and mechanical properties of steels for thermochemical treatment. Mathematical Modelling of Engineering Problems 4(1): 23-25. https://doi.org/ 10.18280/mmep.040105

[16] Qin YH, Wang YY. (2000). Thermodynamics equilibrium of bi3+-cl--h2o system. The Chinese Journal of Nonferrous Metals 10(2): 243-249.

[17] Wang RX, Tang MT, Yang JG, Yang SH, Zhang WH, Tang CB, He J. (2008). Thermodynamics of $\mathrm{zn}(\mathrm{II})$ complex equilibrium in system of $\mathrm{zn}(\mathrm{II})-\mathrm{nh} 3-\mathrm{cl}-$-co32-h2o. The Chinese Journal of Nonferrous Metals 18(s1): s192-s198.

[18] Zhang CF, Yao YL, Zhan J. (2012). Thermodynamics of precipitation-coordination equilibrium in fe2+-ni2+nh3-nh4+-c2o42--h2o system. The Chinese Journal of Nonferrous Metals 22(12): 2938-2943.

[19] Dean JA. (2003). Lange's Handbook of Chemistry (II). Materials and Manufacturing Processes 5(4): 687-688. https://doi.org/ 10.1080/10426919008953291

[20] Cao ZM, Song XY, Qiao ZY. (2008), Thermodynamic modeling software factsage and it application. Chinese Journal of Rare Metals 32(4): 216-219. 